\title{
Geochemical and petrological evidence for subduction- accretion processes in the Archean Eastern Indian Craton
}

\author{
Aniki Saha $^{\mathrm{a}}$, Asish R. Basu ${ }^{\mathrm{a}, *}$, Carmala N. Garzione ${ }^{\mathrm{a}}$, \\ Pradyot K. Bandyopadhyay ${ }^{\mathrm{b}}$, Amitabha Chakrabarti ${ }^{\mathrm{c}}$ \\ a Department of Earth and Environmental Sciences, University of Rochester, Rochester, NY 14627, USA \\ b Department of Geology, Presidency College, Calcutta 700073, India \\ c Department of Geology and Geophysics, Indian Institute of Technology, Kharagpur 721302, India
}

Received 4 August 2003; received in revised form 5 December 2003; accepted 7 January 2004

\begin{abstract}
The composition of sandstones often provides key evidence about the tectonic, weathering and transport processes operating on the surface at the time of deposition. Petrologic and geochemical analyses of little-metamorphosed middle-late Archean sandstones from the Eastern Indian Craton show that the sedimentary rocks were derived from dominantly 3.3-Ga-old amphibolites of the Older Metamorphic Group (OMG) and tonalites of the Older Metamorphic Tonalite Gneisses (OMTG), the two oldest lithologic units of this craton. Chondrite-normalized rare earth element (REE) patterns of the sandstones show a light REE-enriched signature with $(\mathrm{La} / \mathrm{Sm})_{\mathrm{N}}$ varying from 5.2 to 6.7 with no Eu anomaly, while the heavy REEs display flat patterns with $(\mathrm{Gd} / \mathrm{Lu})_{\mathrm{N}}$ values of $0.9-1.6$. Primitive mantle-normalized incompatible and compatible trace element plots of these sandstones demonstrate an overall similarity with global Proterozoic-Archean sandstones, including strong $\mathrm{Nb}-\mathrm{Ta}$ negative anomalies. In an $f_{\mathrm{Sm} / \mathrm{Nd}} \mathrm{vs}$. $\varepsilon_{\mathrm{Nd}}(0)$ diagram, the sandstones plot precisely between the regional amphibolites and tonalites. We infer from the REE abundances and the $f_{\mathrm{Sm} / \mathrm{Nd}}$ vs. $\varepsilon_{\mathrm{Nd}}(0)$ plot that the sandstones represent a bimodal mechanical mixture of OMG and OMTG. The low $\mathrm{Ce} / \mathrm{Pb}$ ratios of these rocks of 1-4 indicate a variably $\mathrm{Pb}$-enriched Archean crust and that the $\mathrm{Ce} / \mathrm{Pb}$ ratio acquired the continental crustal signature, distinctly different from those of the bulk silicate earth and mantle values at least as early as mid-Archean. Strong $\mathrm{Nb}-\mathrm{Ta}$ depletion relative to the primitive mantle suggests the sandstones were derived from subduction-related magmatic arc sources. This latter suggestion is strongly supported by the low $\mathrm{Nb} / \mathrm{Ta}$ and high $\mathrm{Zr} / \mathrm{Sm}$ ratios of these sandstones, identical to Archean tonalite-trondhjemites that require, based on recent trace-element partitioning results, their protoliths to have formed by subduction melting of lowmagnesium amphibolites or metamorphosed hydrous basalts [1,2]. The average $\mathrm{Nd}$ model ages of the sandstones are greater than the Sm-Nd crystallization ages of the OMG and OMTG at $\sim 3.3 \mathrm{Ga}$. The geochemical data presented here can be collectively interpreted to suggest the presence of subduction-accretion processes operational in the midArchean Eastern Indian Craton. Because the OMG and OMTG, the source rocks of the sandstones, formed in a subduction-related arc setting, the basement rocks upon which this arc was constructed must have been older. This observation and the depleted mantle $\mathrm{Nd}$ model ages $\left(\mathrm{T}_{\mathrm{DM}}\right)$ of the sandstones, ranging from 3.6 to $4.0 \mathrm{Ga}$, strongly indicate the presence of continental crust in this Eastern Indian craton older than $3.3 \mathrm{Ga}$ and possibly as old as
\end{abstract}

\footnotetext{
* Corresponding author. Tel.: +1-585-275-2413; Fax: +1-585-244-5689.

E-mail address: abasu@earth.rochester.edu (A. R. Basu).
} 
4.0 Ga.

(C) 2004 Elsevier B.V. All rights reserved.

Keywords: Archean sediments; subduction; trace element geochemistry; Nd isotopes; Eastern Indian Craton

\section{Introduction}

Terrigenous clastic sediments provide important information on their provenance and tectonic setting, as well as on paleoclimate and paleoweathering during sediment deposition. This information can be extracted by examination of the lithology, chemical and isotopic composition, and detrital mineralogy of the sediments [3]. Archean tectonic and sedimentary processes are recorded in contemporaneous sediments from Archean source terranes. The limited occurrence of remnants of Archean crustal fragments and sedimentary rocks has made it difficult to evaluate the relationship between the composition of Archean sedimentary rocks, their sources and tectonic settings [4,5]. In addition, most Archean cratons are high-grade metamorphic terranes, making interpretations difficult for petrologic and geochemical data gathered on these rocks.

Several authors have considered the trace-element geochemistry of Archean siliciclastic rocks to differ from those of post-Archean rocks [6], particularly in terms of the former's more variable Rare Earth Element (REE) patterns, lower total REE content and by their general lack of europium anomalies. Such differences, if true, might have implications for the mode of origin of the Earth's early crust, or they might reflect an agedependent preservation bias. Geochemical study of Archean sedimentary rocks, which reflects the nature of their sources, thus can help in constraining the composition of the upper crust during the Archean and the tectonic setting in which the Archean crust was formed. REEs in conjunction with $\mathrm{Nd}$ isotopes are shown to be useful for characterizing provenance $[7,8]$. REEs are generally transported unfractionated by fine-grained siliciclastic sediments and hence reflect the average REE composition of their sources [9]. A temporal dimension can also be added to the sedimentary provenance study by the $\mathrm{Nd}$ isotopic model ages, providing extraction ages of the sediment's parent protoliths from a depleted mantle source $\left(\mathrm{T}_{\mathrm{DM}}\right)$ [10].

The present study represents a comprehensive investigation of the provenance of a relatively fresh succession of Archean sandstones from the Eastern Indian Craton, one of the world's rare, well-preserved and least metamorphosed Archean terranes [11-13]. These sedimentary rocks are particularly interesting because of their antiquity (at least $2.8 \mathrm{Ga}$ in age), lower grade of metamorphism (low greenschist facies) and lack of penetrative deformation. Our sedimentological and petrographic examinations, combined with high precision trace element and $\mathrm{Nd}$-isotopic analyses for model ages, enabled us to draw several inferences concerning: (1) the sources of these Archean sediments; (2) trace element characterization and the nature of the $>3.0-$ Ga-old continental crust of this craton; (3) the provenance age of the protoliths of the sandstones; and (4) the mode of origin of the igneous sources of the sandstones, the amphibolites (metabasalts) and tonalite suite of rocks of this craton by ancient subduction.

\section{Geologic settings and samples for this study}

The Eastern Indian Craton (Fig. 1) is bounded by the arcuate Copper Belt thrust in the north and the Sukinda thrust to the south, neither of whose ages are well constrained. The mid-Proterozoic Eastern Ghat Granulite belt is in the southwest and the relatively high-grade metamorphic Satpura Orogenic belt of middle Proterozoic age is situated to the northwest of the craton. The Singhbhum Granite batholithic complex of $3292 \pm 51$ Ma age $[14,15]$ occupies the major portion of this craton. Remnants of ancient rocks that include the Older Metamorphic Group (OMG), which consists of meta-igneous and meta-sedimentary rocks of amphibolite facies 


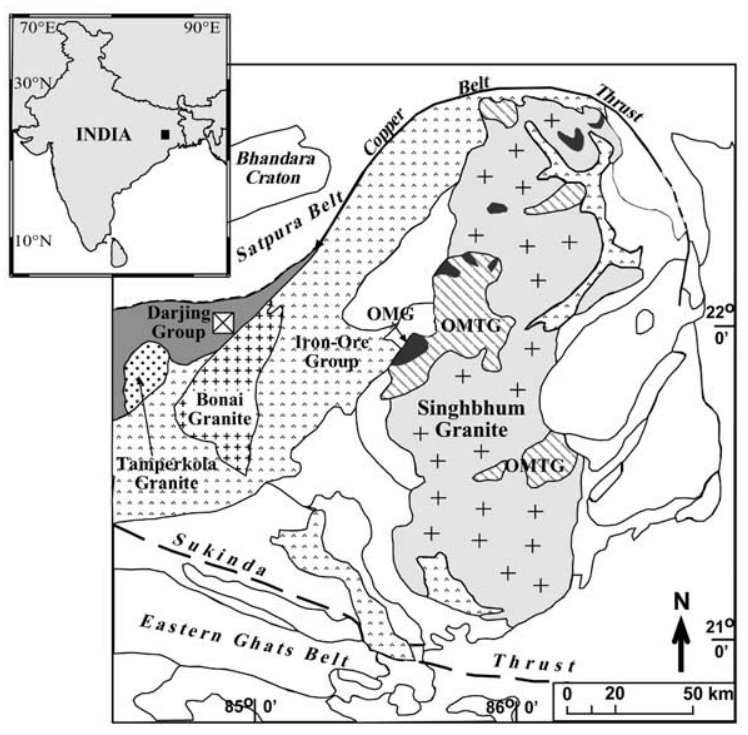

Fig. 1. Geological map of the Eastern Indian Craton in the Singhbhum-Orissa region of the Indian continent (see inset) modified after [13] and [17]. The current study area is to the north of the Bonai Granite. The sandstones of this study are from the Darjing Group, west of the Singhbhum Granite. Samples analyzed are from a sedimentary succession shown by the crossed box. Abbreviations: OMG, Older Metamorphic Group; OMTG, Older Metamorphic Tonalite Gneisses. The ages of the relevant rocks are: Tamperkola Granite, $\sim 2.8 \mathrm{Ga}$; Bonai Granite, $3.2 \mathrm{Ga}$; Singhbhum Granite Complex, $\sim 3.1 \mathrm{Ga}$; OMTG, $\sim 3.3 \mathrm{Ga}$; OMG, $\sim 3.3 \mathrm{Ga}$. See text for geologic-lithologic details.

[16], and the Older Metamorphic Tonalite Gneisses (OMTG) are found within the batholithic complex. These enclaves range in size from a few square meters to several hundred square kilometers (Fig. 1). The OMTG intrude the OMG amphibolites, indicating that the latter form the oldest rock unit in the area. The presence of enclaves of the OMG-OMTG assemblage throughout the batholithic complex indicates that these units were of extensive nature. This batholith itself is overlain on all sides by the Iron Ore Group. At places, the Iron Ore Group is intruded by the youngest phases of batholithic intrusions, although details of age relationships between the Iron Ore Group and the Singhbhum Granite are yet to be established. The Iron Ore Group has been intruded by the Bonai Granite in the west (Fig. 1). Remnants of quartzite from the Iron Ore Group and metabasic rocks are pre- served within the Bonai Granite $(\mathrm{Pb}-\mathrm{Pb}$ age of $3163 \pm 126 \mathrm{Ma}$ [17]), which is thought to be coeval with the Singhbhum Granite.

A 200-m-thick succession of dominantly sandto-pebble-size siliciclastic rocks is preserved on top of the Iron Ore Group and the Bonai Granite in the northwestern part of the craton (Fig. 1). The lower part of this succession consists of alternating matrix-supported conglomerate and feldspathic quartzite, overlain by dominantly coarse to fine-grained feldspathic arenite. The most common sedimentary structure in this succession is large-scale trough cross-beds. Other sedimentary structures include scour-and-fill structures and symmetrical and asymmetrical ripple cross-stratifications. Field and stratigraphic relations of this unit are described in an earlier study [18]. The preliminary sedimentologic study suggests that the sandstones were deposited in a marginal marine depositional setting and the paleoflow direction was towards the northwest [18].

The above sedimentary rocks have been included within the Birtola Formation of the Darjing Group [19]. Rocks overlying the Birtola Formation have been intruded by the Tamperkola Granite with an age of $2809 \pm 12$ Ma from $\mathrm{U}-\mathrm{Pb}$ dating of zircons [20]. Thus the age of deposition of these sandstones can be constrained between the age of intrusion of the Bonai Granite $(\sim 3.16 \mathrm{Ga})$ and that of the Tamperkola pluton ( $2.8 \mathrm{Ga})$.

Fourteen sandstone samples were collected for this study from the Birtola Formation of the Darjing Group from the area shown by the crossed-box in Fig. 1. Of the fourteen samples that were analyzed for a thorough petrographic and modal analysis, nine were selected for trace element and isotopic study. These nine samples represent a 200 -m-thick contiguous sedimentary succession of the Birtola Formation.

\section{Petrology of the Archean sandstones and their source rocks}

\subsection{Lithology of the source area}

The Eastern Indian Craton is a mosaic of sev- 
eral geological units (Fig. 1). The OMG, the oldest unit in this area, is similar in lithology to other ancient Archean terranes of the world by the absence of ultramafic or komatiitic lavas [12], a situation which is duplicated in the Slave and North China cratons [21]. The OMG consists of dominantly pelitic schists with several thick bands of para-amphibolites, along with quartzite, quartzsericite schist and quartz-magnetite-cummingtonite schist. These metasediments are extensively intruded by sill-like mafic intrusives, now metamorphosed to ortho-amphibolites and rare talctremolite and anthophyllite schists. Subhedral tourmaline grains and elongate-elliptical zircon are common accessories in these pelitic schists $[12,22]$. The tonalites of the OMTG, which intrude the OMG, consist mainly of plagioclase and quartz with biotite and occasional hornblende $[11,13,15]$. The Singhbhum Granite, varying from basic granodiorite through adamellite to acid potassic granite, comprises plagioclase, quartz, orthoclase, and chloritized hornblende and mica. The Bonai Granite crops out (Fig. 1) west of the Singhbhum Granite and is thought to be a continuation of the Singhbhum Granite.

The Iron Ore Group is to be found in the northwest of the craton (Fig. 1) resting unconformably on a sequence of volcanic rocks. Banded chert and jasper along with quartzite dominate part of the Iron Ore Group sequence, while shale and banded hematite quartzite with hematite ore dominate the other part of the sequence. Ferruginous clastic metasedimentary rocks including phyllite, tuff and chlorite-actinolite schists are also significant members of the Iron Ore Group.

\subsection{Petrology of the sandstones}

Modal analysis of the sandstones of the Birtola Formation was determined to characterize source rock composition and to facilitate the interpretation of the trace element and isotopic data. Standard petrographic thin-sections of fourteen samples were used for point counting. Counts varied from 400-500 data points depending on the grain size of the sandstones. The Gazzi-Dickinson point-counting method [23] was used to make possible comparisons with tectonic provenance models [24].

The parameters for the modal point-count analysis are given in Table 1 along with the recalculated data. Because a major conclusion of this study, based on trace elements and $\mathrm{Nd}$ isotopes, is supported by the petrography of the sandstones, the different constituents of the sandstones are described below.

(1) Monocrystalline quartz (Qm). Monocrystalline quartz, with undulose extinction, constitutes an average of $\sim 87 \%$ of the samples. Ubiquitous marginal granulation and recrystallization caused difficulty in assessing the original roundness of the quartz grains, but chloritic material bordering some quartz grains preserves the originally

Table 1

Results of point-counting of 14 thin-sections of sandstone samples. 400-500 points were counted per sample

\begin{tabular}{|c|c|c|c|c|c|c|}
\hline \multirow[b]{2}{*}{ Sample } & \multicolumn{3}{|c|}{ QFL data } & \multicolumn{3}{|c|}{$\mathrm{Q}_{\mathrm{m}} \mathrm{FL}_{\mathrm{t}}$ data } \\
\hline & Q & $\mathrm{F}$ & $\mathrm{L}$ & $\mathrm{Q}_{\mathrm{m}}$ & $\mathrm{F}$ & $\mathrm{L}_{\mathrm{t}}$ \\
\hline $23 / 96$ & 81.0 & 18.3 & 0.7 & 80.7 & 18.3 & 1.0 \\
\hline $24 / 96$ & 90.3 & 9.3 & 0.3 & 88.7 & 9.3 & 2.0 \\
\hline $25 / 96$ & 83.3 & 14.7 & 2.0 & 80.3 & 14.7 & 5.0 \\
\hline $27 / 96$ & 93.6 & 6.4 & 0.0 & 87.9 & 6.4 & 5.7 \\
\hline $28 / 96$ & 98.3 & 1.3 & 0.3 & 83.7 & 1.3 & 15.0 \\
\hline $30 / 96$ & 93.0 & 5.3 & 1.7 & 88.7 & 5.3 & 6.0 \\
\hline $31 / 96$ & 89.3 & 7.7 & 3.0 & 87.0 & 7.7 & 5.3 \\
\hline $33 / 96$ & 90.7 & 6.7 & 2.7 & 87.0 & 6.7 & 6.3 \\
\hline $\mathrm{P} 1 / 96$ & 87.3 & 11.3 & 1.3 & 85.7 & 11.3 & 3.0 \\
\hline $\mathrm{P} 3 / 96$ & 82.8 & 16.2 & 1.0 & 80.3 & 16.0 & 3.7 \\
\hline P4/96 & 87.0 & 12.3 & 0.7 & 86.3 & 12.3 & 1.3 \\
\hline P6/96 & 79.7 & 19.7 & 0.7 & 78.0 & 19.7 & 2.3 \\
\hline PRM & 88.3 & 11.0 & 0.7 & 85.0 & 11.0 & 4.0 \\
\hline $\mathrm{R} / 96$ & 80.3 & 19.0 & 0.7 & 78.0 & 19.0 & 3.0 \\
\hline Average & 87.5 & 11.4 & 1.1 & 84.1 & 11.4 & 4.5 \\
\hline Std. Dev. & 5.6 & 5.6 & 0.9 & 3.9 & 5.6 & 3.5 \\
\hline
\end{tabular}

The data are shown recalculated with respect to the end members of the ternary plots. Key: Qm=Monocrystalline Quartz; Qp = Polycrystalline Quartz; C = Chert; $\mathrm{F}=$ Total Feldspar Grains; $\mathrm{P}=$ Plagioclase feldspars; $\mathrm{K}=$ Potash-feldspar; L = Lithics. For QFL data: $\mathrm{Q}=$ Total quartzose grains $(=\mathrm{Qm}+\mathrm{Qp}+\mathrm{C}) ; \mathrm{F}=$ Total Feldspar Grains $(=\mathrm{P}+\mathrm{K}) ; \mathrm{L}=$ Total Lithic Grains (= L). QFL $\% \mathrm{Q}=100 \mathrm{Q} /(\mathrm{Q}+\mathrm{F}+\mathrm{L}) ; \mathrm{QFL} \% \mathrm{~F}=$ $100 \mathrm{~F} /(\mathrm{Q}+\mathrm{F}+\mathrm{L}) ; \mathrm{QFL} \% \mathrm{~L}=100 \mathrm{~L} /(\mathrm{Q}+\mathrm{F}+\mathrm{L})$. For $\mathrm{Q}_{\mathrm{m}} \mathrm{FL}_{\mathrm{t}}$ data: $\mathrm{Qm}=$ Monocrystalline Quartz $(=\mathrm{Qm}) ; \mathrm{F}=$ Total Feldspar Grains $(=\mathrm{P}+\mathrm{K}) ; \mathrm{L}_{\mathrm{t}}=$ Total Lithic Grains including polycrystalline quartz $(=\mathrm{Qp}+\mathrm{C}+\mathrm{L}) \mathrm{Q}_{\mathrm{m}} \mathrm{FL}_{\mathrm{t}} \% \mathrm{Q}_{\mathrm{m}}=100 \mathrm{Q}_{\mathrm{m}} /\left(\mathrm{Q}_{\mathrm{m}}+\mathrm{F}+\mathrm{L}_{\mathrm{t}}\right)$; $\mathrm{QmFLt} \% \mathrm{~F}=100 \mathrm{~F} /(\mathrm{Qm}+\mathrm{F}+\mathrm{Lt}) ; \mathrm{QmFLt} \% \mathrm{Lt}=100 \mathrm{Lt} /(\mathrm{Qm}+\mathrm{F}+$ $\mathrm{Lt})$. 
rounded to sub-rounded nature of the grains. The probable sources of the quartz grains were the OMTG and possibly the Singhbhum Granite [25].

(2) Polycrystalline quartz ( $Q p$ ). Polycrystalline quartz fragments make up an average of $\sim 2.5 \%$ of the samples counted. These grains show polygonized, crenulated and sutured boundaries. Microcrystalline quartz grains and metachert (C) (usually $<2 \%$ ) occur as rounded clasts. Potential sources of these polycrystalline grains are the siltites and cherts of the Iron Ore Group as well as OMG source terrane.

(3) Feldspar ( $F$ ). An average of $10 \%$ of the framework grains are potassium feldspar (K) while plagioclase feldspar $(\mathrm{P})$ is generally less than $3 \%$. Most of the potassium feldspar is orthoclase with some microcline. Alteration of the feldspars varied from fresh to highly sericitized, while the grain shape varied from angular to wellrounded single crystals (Fig. 2a). The feldspars may have been derived from amphibolites as well as the tonalites and granites from the source area. Fine-grained aggregates of potassium feldspar along with quartz (Fig. 2b), observed in the thin-sections, are probably derived from the igneous rocks.

(4) Lithic fragments ( $L)$. Lithic grains average to $\sim 1 \%$ of the samples. These grains consist of chert with biotite-chlorite and highly sericitized fine-grained mafic clasts (probably amphibolite) (Fig. 2c). Large aggregates consisting exclusively of biotite, chlorite, and other micaceous minerals were observed. Grain shape and distinct grain boundaries suggest that instead of being diagenetic products these aggregates are the alteration products of amphibolite clasts.

(5) Accessory minerals. Well-rounded zircons, rutile and opaques are common accessories. For reasons discussed in [24], accessory minerals were excluded from the modal point counts.

Overall, the sandstones are moderately to well-
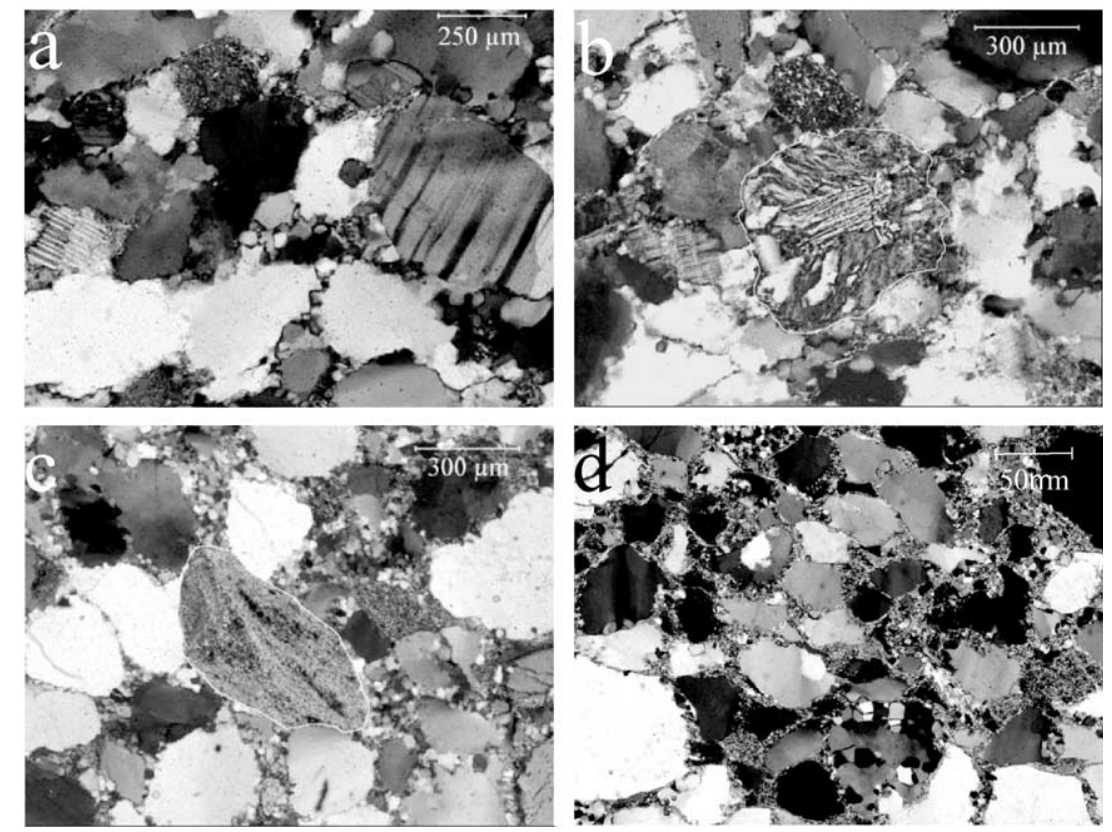

Fig. 2. Photomicrographs of the Archean sandstones showing some of their characteristic petrographic features. (a) A grain of well-rounded fresh plagioclase is on the right while a smaller feldspar grain is to the left, both showing plastic deformation. Quartz clasts in the lower part show suturing and marginal crystallization. (b) A typical lithic quartz-feldspar clast in the middle, probably derived from an OMTG source. (c) A metamorphic lithic clast consisting mainly of biotite, chlorite and sericite, probable alteration products of amphibolite of OMG source. (d) The general texture of the sandstones is shown here. Note pseudomatrix of chlorite-sericite defining the framework quartz grain boundaries. Rock shows evidence of post-depositional plastic deformation and some recrystallization. All four photomicrographs were taken under crossed nicols. 
sorted with sub-angular to well-rounded grains. The cement in the sandstones is dominantly quartzose. Most of the 'pseudomatrix' (1-25\%), which consists of sericite and chlorite, formed from in situ alteration of clay minerals and lithic grains. The matrix is not post depositional, as it exceeds the maximum volume of reported infiltrated material of 3-9\% [26] and occludes pore space instead of forming grain coatings [27] (Fig. 2d).

Dissolution and decomposition of lithic grains during and after the diagenesis of sandstones can increase the amount of matrix [28-30]. This is particularly important for ancient sedimentary rocks that have undergone advanced diagenesis. In the sandstones of this study there is variable amount of pseudomatrix, all showing chlorite grade of metamorphism. The sandstones also exhibit pressure solutions (Fig. 2d). Assuming that the entire matrix was derived from lithic clasts, recalculating the matrix into lithic grains in the point counting would increase the modal amount of the lithics $(2-15 \%)$ [29]. The effect of this recalculation is discussed below.

\subsection{Modal sand composition}

Uniformity in the composition of the sandstones throughout the section suggests that no change in the provenance occurred throughout the deposition of the sandstone succession. In both the QFL (Quartz-Feldspar-Lithics) and $\mathrm{Q}_{\mathrm{m}} \mathrm{FL}_{\mathrm{t}}$ (Monocrystalline Quartz-Feldspar-Total Lithics) ternary plots (Fig. 3a,b), the sandstones plot in the continental block provenance field [24,31], indicating enrichment in quartz and feldspar while deficient in lithic fragments (average $\% \mathrm{QFL}=86,11,3)$. However, when the recalculated lithics are taken into consideration, an increase in the modal value of the lithics would probably shift some of the sandstones to the recycled orogen field (dashed arrows in Fig. 3a,b) [24,31]. Although we cannot infer positively from Fig. 3 the tectonic setting in which these sandstones were deposited, the above detailed petrographic study provides supporting evidence for the interpretation of the geochemical data as described in Section 4.

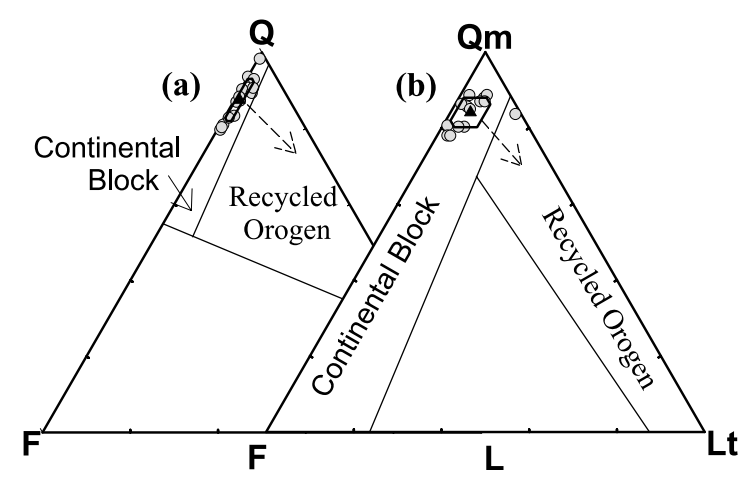

Fig. 3. Modal (a) QFL and (b) QmFLt ternary plots for the sandstones. The different provenance fields are from [24,31]. The sandstones plot in the continental block provenance field. Potential positions of the sandstones in the recycled orogen field, on recalculation of the pseudomatrix into lithics, are shown by dashed arrows (see text for discussion). The gray circles represent individual plots, while the average is indicated by the filled triangle. The hexagon in each plot indicates the standard deviation from the mean.

\section{Trace elements and Nd,Sr-isotope geochemistry}

\subsection{Analytical methods}

Nine sandstone samples were analyzed for trace element concentrations and $\mathrm{Sr}$ and $\mathrm{Nd}$ isotopic systematics. Trace elements were determined on an Inductively Coupled Plasma Mass Spectrometer (ICPMS PQ II+), while the radiogenic isotopic ratios were measured on the Thermal Ionization Mass Spectrometer (TIMS VG Sector), both at the University of Rochester, NY. For the ICPMS analyses, digested 100-mg rock powder samples were diluted to $100 \mathrm{ml}$ of $5 \% \mathrm{HNO}_{3}$ solution and spiked with $\sim 10$ ppb internal standards of In, Cs, Re and Bi. Table 2 shows the concentrations obtained by using BCR-2 and BIR-2 as known standards. For $\mathrm{Nd}$ and $\mathrm{Sr}$ isotopic analyses, between 100 and $200 \mathrm{mg}$ of the powdered rock samples were digested in $\mathrm{HF}-$ $\mathrm{HNO}_{3} . \mathrm{Sm}$ and $\mathrm{Nd}$ concentrations were measured by isotope dilution using a mixed spike $\left({ }^{149} \mathrm{Sm}-\right.$ ${ }^{150} \mathrm{Nd}$ ) and $\mathrm{Nd}$ - and Sr-isotopes were measured using the same procedures established for our laboratory at the University of Rochester [8]. Procedural blanks were 400, 200 and 100 pg, respectively for $\mathrm{Sr}, \mathrm{Nd}$ and $\mathrm{Sm}$. 
Table 2

25 trace element concentrations determined by ICP-MS of the sandstone samples

\begin{tabular}{|c|c|c|c|c|c|c|c|c|c|}
\hline Samples & $23 / 96$ & $24 / 96$ & $25 / 96$ & $27 / 96$ & $30 / 96$ & $31 / 96$ & PRM/84 & $\mathrm{p} 3 / 96$ & P6/96 \\
\hline $\mathrm{Ba}$ & & 268.9 & 331.5 & 147.8 & 356.8 & 332.0 & 271.9 & 606.6 & 332.5 \\
\hline $\mathrm{Rb}$ & 77.4 & 74.6 & 56.4 & 42.9 & 92.3 & 85.4 & 69.8 & 141.9 & 59.6 \\
\hline $\mathrm{Sr}$ & 74.0 & 32.5 & 55.4 & 14.1 & 36.6 & 42.6 & 34.7 & 167.3 & 59.6 \\
\hline $\mathrm{Pb}$ & 13.2 & 5.7 & 11.1 & 6.9 & 11.6 & 10.9 & 10.1 & 12.8 & 8.8 \\
\hline $\mathrm{La}$ & 14.7 & 8.1 & 18.2 & 3.6 & 8.2 & 7.8 & 6.1 & 31.4 & 9.9 \\
\hline $\mathrm{Ce}$ & 26.1 & 10.7 & 31.9 & 7.2 & 14.2 & 12.6 & 11.7 & 50.0 & 15.5 \\
\hline $\operatorname{Pr}$ & 2.6 & 1.4 & 3.3 & 0.7 & 1.5 & 1.4 & 1.0 & 5.8 & 1.8 \\
\hline $\mathrm{Nd}$ & 8.8 & 4.8 & 9.8 & 2.4 & 5.1 & 5.6 & 4.2 & 23.4 & 6.6 \\
\hline $\mathrm{Sm}$ & 1.6 & 1.0 & 2.0 & 0.49 & 1.01 & 1.12 & 0.81 & 4.4 & 1.04 \\
\hline $\mathrm{Eu}$ & 0.38 & 0.22 & 0.36 & 0.11 & 0.26 & 0.25 & 0.18 & 0.83 & 0.23 \\
\hline Gd & 1.11 & 0.60 & 1.37 & 0.39 & 0.74 & 0.68 & 0.47 & 2.48 & 0.84 \\
\hline $\mathrm{Tb}$ & 0.17 & 0.09 & 0.21 & 0.07 & 0.12 & 0.11 & 0.07 & 0.39 & 0.13 \\
\hline Dy & 1.02 & 0.54 & 1.34 & 0.45 & 0.75 & 0.72 & 0.39 & 2.25 & 0.83 \\
\hline Ho & 0.20 & 0.11 & 0.27 & 0.09 & 0.15 & 0.15 & 0.07 & 0.42 & 0.16 \\
\hline $\mathrm{Er}$ & 0.62 & 0.31 & 0.83 & 0.28 & 0.44 & 0.48 & 0.22 & 1.25 & 0.46 \\
\hline Tm & 0.10 & 0.05 & 0.13 & 0.04 & 0.07 & 0.08 & 0.04 & 0.19 & 0.07 \\
\hline $\mathrm{Yb}$ & 0.65 & 0.31 & 0.93 & 0.30 & 0.48 & 0.58 & 0.26 & 1.41 & 0.50 \\
\hline $\mathrm{Lu}$ & 0.10 & 0.05 & 0.14 & 0.04 & 0.07 & 0.09 & 0.04 & 0.21 & 0.07 \\
\hline Y & 7.0 & 3.6 & 9.4 & 3.4 & 5.2 & 5.5 & 2.3 & 14.8 & 5.5 \\
\hline Th & 6.3 & 3.1 & 5.9 & 2.3 & 5.5 & 5.2 & 3.8 & 19.3 & 4.6 \\
\hline U & 3.1 & 1.36 & 3.0 & 1.36 & 2.1 & 2.3 & 2.4 & 5.5 & 1.67 \\
\hline $\mathrm{Zr}$ & 101.6 & 35.2 & 135.1 & 48.9 & 92.9 & 175.0 & 49.1 & 143.2 & 72.3 \\
\hline Hf & 2.2 & 0.92 & 3.1 & 1.24 & 2.2 & 3.8 & 1.25 & 3.5 & 1.67 \\
\hline $\mathrm{Nb}$ & 3.0 & 1.65 & 3.8 & 1.68 & 3.1 & 3.1 & 2.7 & 11.1 & 5.0 \\
\hline $\mathrm{Ta}$ & 0.39 & 0.18 & 0.41 & 0.27 & 0.36 & 0.40 & 0.27 & 1.36 & 0.62 \\
\hline $\mathrm{Eu} / \mathrm{Eu}^{*}$ & 0.90 & 0.93 & 0.70 & 0.81 & 0.90 & 0.92 & 1.00 & 0.85 & 0.75 \\
\hline$\left(\mathrm{La}_{\mathrm{n}} / \mathrm{Sm}_{\mathrm{n}}\right)$ & 6.28 & 6.25 & 6.72 & 5.18 & 5.15 & 5.55 & 5.81 & 5.98 & 6.01 \\
\hline$\left(\mathrm{Gd}_{\mathrm{n}} / \mathrm{Lu}_{\mathrm{n}}\right)$ & 1.40 & 1.60 & 1.22 & 1.18 & 1.38 & 0.95 & 1.31 & 1.48 & 1.47 \\
\hline $\mathrm{Nb} / \mathrm{Ta}$ & 7.82 & 9.12 & 9.23 & 6.26 & 8.56 & 7.93 & 9.90 & 8.13 & 8.09 \\
\hline $\mathrm{Ce} / \mathrm{Pb}$ & 1.98 & 1.90 & 2.88 & 1.04 & 1.23 & 1.16 & 1.16 & 3.91 & 1.77 \\
\hline
\end{tabular}

The concentrations shown are in ppm $(\mu \mathrm{g} / \mathrm{g})$. Analytical uncertainties are less than $5 \%$, commonly at $2 \%$ for the REEs.

\subsection{Trace element geochemistry}

Chondrite-normalized REE patterns for the sandstones are shown in Fig. 4. The REE concentrations vary from 10 to 100 times chondrite for the light rare earth element (LREE) La, while the heavy rare earth elements (HREE) Gd to Lu vary from 1 to 10 times the chondritic abundance. The concentration of REE in the sandstones is consistent with the observation that in general Archean sedimentary rocks have lower REE abundances $[4,32,33]$. Total REE concentrations vary from $\sim 16$ to $\sim 71 \mathrm{ppm}$ with the exception of a sandstone (sample P3/96) that contains a higher percentage of the pseudomatrix. Variation in the concentrations of the REEs can be attributed to variable modal quantities of quartz and that most of the REEs are concentrated in the fine-grained matrix of clay minerals, sericite, biotite and chlorite [33]. $\quad \mathrm{Eu} / \mathrm{Eu}^{*} \quad\left(\mathrm{Eu} / \mathrm{Eu}^{*}=\mathrm{Eu}_{\mathrm{N}} \sqrt{ }\left(\mathrm{Sm}_{\mathrm{N}}\right) \cdot\left(\mathrm{Gd}_{\mathrm{N}}\right)\right.$ where ' $\mathrm{N}$ ' denotes chondrite-normalized values [4]) varies mostly between 0.90 and 1.0 , indicating virtually the absence of any significant europium anomaly. Specifically, the REE patterns show a LREE enrichment with $(\mathrm{La} / \mathrm{Sm})_{\mathrm{N}}$ varying from $\sim 5$ to $\sim 7$ while the $(\mathrm{Gd} / \mathrm{Lu})_{\mathrm{N}}$ varies from 0.9 to 1.6 indicating the flat nature of the HREE. A combination of a relatively flat HREE pattern and $\mathrm{Eu} / \mathrm{Eu}^{*}$ of $\sim 0.8$ is characteristic of sedimentary rocks from other Archean high grade terranes [4,9]. An interesting feature is the small depletion in $\mathrm{Ho}-\mathrm{Er}$ relative to $\mathrm{Yb}-\mathrm{Lu}$, which can be 


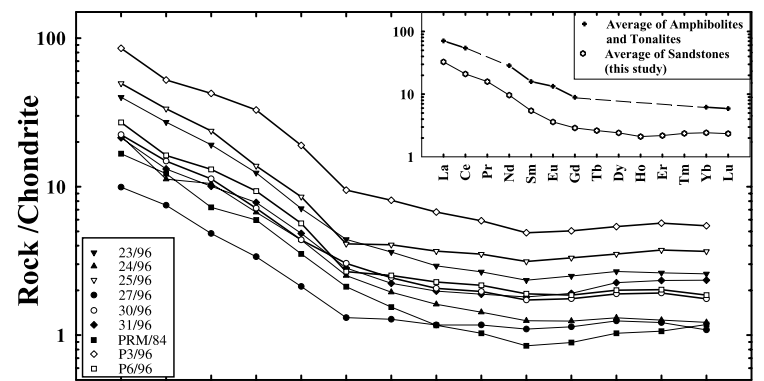

La Ce Pr Nd Sm Eu Gd Tb Dy Ho Er Tm Yb Lu

Fig. 4. Chondrite-normalized rare earth element patterns of the sandstones of this study from the Eastern Indian Craton. The siliciclastic rocks display a broadly similar pattern with characteristically light REE enrichment, flat heavy REE patterns with the absence of europium anomaly. Overall, these patterns are similar to Archean sediments [5]. The average REE pattern (inset) of the sandstones shows an overall similar pattern with that of the adjacent 3.3-Ga-old tonalites and amphibolites. See text for details.

explained by small addition of LREE depletedHREE enriched minerals with no $\mathrm{Eu}$ anomaly, such as amphibolitic garnet [34] or zircon. These minerals typically show La values greater than 10 times chondrite and $\mathrm{Lu}$ values at 100 times chondrite.

REE patterns of the sandstones are compared in Fig. 1 to the REE patterns of the amphibolites of the OMG and the tonalites from the OMTG. REE data determined previously [15] by neutron activation analysis are available for eight amphibolites and seven tonalites from the adjacent region of this craton (Fig. 1). These tonalites show an enriched LREE pattern, with high $(\mathrm{La} / \mathrm{Sm})_{\mathrm{N}}$ values of $\sim 9$, and depleted HREE values, with $(\mathrm{Gd} /$ $\mathrm{Lu})_{\mathrm{N}}$ value of $\sim 3$. The amphibolites on the other hand show variable LREE patterns from enriched LREE patterns $\left(\mathrm{La} / \mathrm{Sm}_{\mathrm{N}} \sim 2.7\right)$ to a depleted pattern $\left(\mathrm{La} / \mathrm{Sm}_{\mathrm{N}}=0.9\right)$. However, all the amphibolites show a flat HREE pattern with $(\mathrm{Gd} / \mathrm{Lu})_{\mathrm{N}}$ varying between 0.9 and 1.2. The average REE concentrations of the amphibolites and tonalites (averaged from 8 amphibolites and 7 tonalites from [15]) are shown in Fig. 4 (filled symbols, inset). This average REE pattern shows a remarkable similarity to the average of the REE concentrations of the nine sandstones (open symbols, inset in Fig. 4). The REE pattern of the average of the amphibolites and tonalites shows a (La/
$\mathrm{Sm})_{\mathrm{N}}$ value of 4.4 and a $(\mathrm{Gd} / \mathrm{Lu})_{\mathrm{N}}$ value of 1.5 , while the average of the nine sandstones gives a value of 6.0 for $(\mathrm{La} / \mathrm{Sm})_{\mathrm{n}}$ and 1.2 for $(\mathrm{Gd} / \mathrm{Lu})_{\mathrm{n}}$. The strong similarity between the average values of the amphibolites and the tonalites with the sandstone averages indicates that the REE geochemical characteristic of the sandstones is the reflection of a bimodal mechanical mixing between the amphibolites and tonalites.

Other incompatible and compatible trace element patterns including the REEs of the Archean sandstones are shown in Fig. 5, normalized to the primitive mantle. Overall, the sandstones show a broadly similar pattern with a strongly positive $\mathrm{Zr}-\mathrm{Hf}$ and depleted $\mathrm{Nb}-\mathrm{Ta}$ patterns. The $\mathrm{Nb}-$ Ta depletion is typically a characteristic of upper continental crust of all ages including the Archean, although high precision trace element data in Archean continental crustal rocks are sparse [32]. When trace elements are normalized to the NASC (North American Shale Composite), positive $\mathrm{Zr}$ and $\mathrm{Hf}$ spikes are noticeable for the sandstones, which perhaps suggests accumulation of heavy minerals like rutile and zircon in the sandstones. In the inset of Fig. 5 the averages for the trace elements of the sandstones of this study are shown along with those of the Archean and Proterozoic sandstone [32]. Compared to the average Archean and Proterozoic sandstones, the average of the sandstones from this study shows more

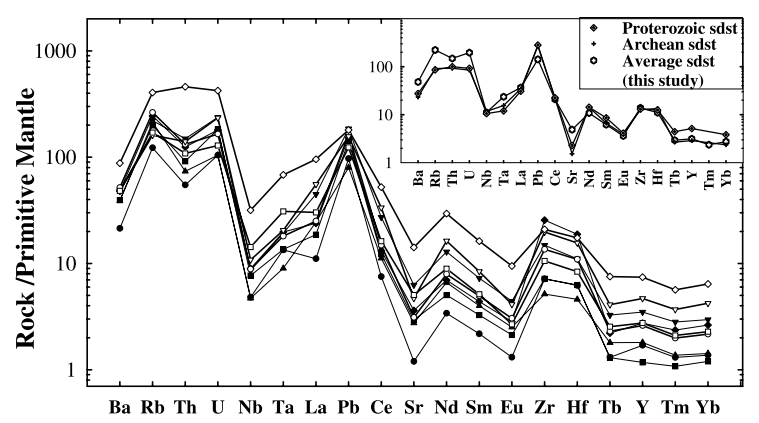

Fig. 5. Primitive mantle normalized trace element patterns of the sandstones from the Eastern Indian Craton. Symbols are the same as in Fig. 4. The patterns are broadly similar except for sample P3/96, which shows an absence of thorium depletion. Abbreviation: sdst, sandstones. Inset shows primitive mantle-normalized trace element patterns of the average sandstones of this study compared with the average Proterozoic, and Archean sandstones [32] (see text for discussion). 


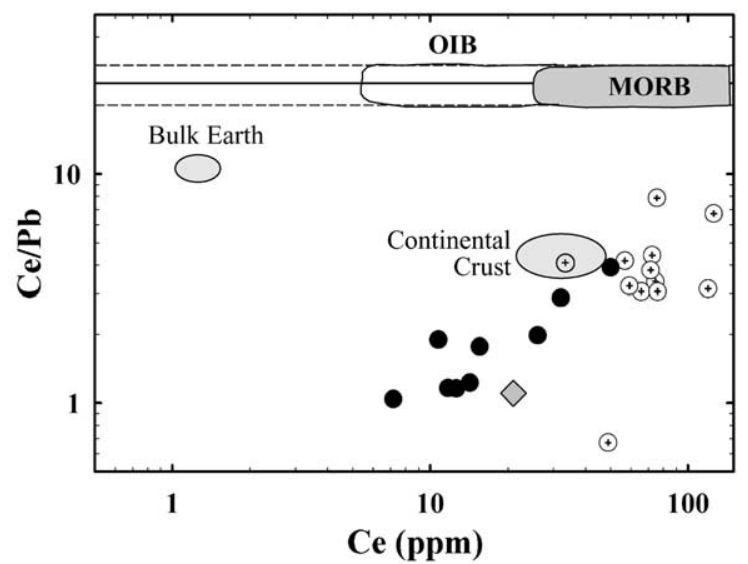

Fig. 6. $\mathrm{Ce} / \mathrm{Pb}$ ratios and $\mathrm{Ce}$ concentrations in the sandstones (filled circles) compared with those of oceanic basalts (MORBs and OIBs), the bulk earth and continental crust [35-37]. Also shown are the shales from the Pilbara Supergroup [6] indicated by open circles with crosses and the average archean sandstone [32] shown by a diamond. Note the generally positive correlation of the data points.

depleted $\mathrm{Th}$ compared to $\mathrm{Rb}$ and $\mathrm{U}$ and a less conspicuous depletion of $\mathrm{Sr}$. The sandstones show higher $\mathrm{Ba} / \mathrm{Th}$ values when compared to the average Archean and Proterozoic sandstones. The rocks in general show super-primitive mantle $\mathrm{La} / \mathrm{Sm}$ and $\mathrm{Th} / \mathrm{Ta}$ values, with sub-primitive mantle values of $\mathrm{Nb} / \mathrm{Th}$ and $\mathrm{Nb} / \mathrm{U}$. Another noteworthy aspect is the variation in the $\mathrm{Ce} / \mathrm{Pb}$ values between 1.0 and 3.9 (Table 2), indicating that the Archean continental crust was already enriched in $\mathrm{Pb}$ with respect to $\mathrm{Ce}$ compared to the primitive mantle and the present day mantle as represented by ocean island basalts (OIBs) and mid-ocean ridge basalts (MORBs) that show a $\mathrm{Ce} / \mathrm{Pb}$ value of $25 \pm 5$ [35,36]. $\mathrm{Nb}$ and $\mathrm{Ta}$ concentrations in the sandstones show a strong positive correlation with an $\mathrm{R}^{2}=0.989$, possibly indicating that these two elements are controlled by the same mineralogical phases, probably rutile and the opaques. The sandstone sample P3/96 with the highest concentration of $\mathrm{Nb}$ and $\mathrm{Ta}$ also shows the highest concentration of opaques and rutile, as determined from thin-section observations.

$\mathrm{On} \mathrm{a} \mathrm{Ce} / \mathrm{Pb}$ vs. Ce concentration plot (Fig. 6), the $\mathrm{Ce} / \mathrm{Pb}$ ratios of the sandstones lie between 1 and 4, which is below the average continental crustal value of 4-5 [35-37]. Other reference data points in this diagram are the bulk earth and oceanic basalt reservoirs from the literature. Pilbara Supergroup shales of Archean age [6] along with the average Archean cratonic sandstones [32] are all plotted in Fig. 6 for comparison. The sandstones of this study plot in an array over a range of Ce concentration of 7-50 ppm, correlating positively with their $\mathrm{Ce} / \mathrm{Pb}$ ratios indicating possibly a mixture between the amphibolites from the OMG and the tonalites from the OMTG.

Partitioning of $\mathrm{Nb}, \mathrm{Zr}$, Ta and Sm during melting of amphibolites in subduction zone environments has recently been considered [38] for tonalitic magma genesis. We consider such data useful in the present context. On a $\mathrm{Nb} / \mathrm{Ta}$ vs. $\mathrm{Zr} / \mathrm{Sm}$ plot (Fig. 7), our analyzed sandstones as well as other relevant rocks from the literature are shown. The intersection of the two lines shows the primitive mantle ratios for $\mathrm{Nb} / \mathrm{Ta}$ and $\mathrm{Zr} / \mathrm{Sm}$ as a reference point. For comparison, the fields of modern MORBs, OIBs and island-arc basalts (IABs) are

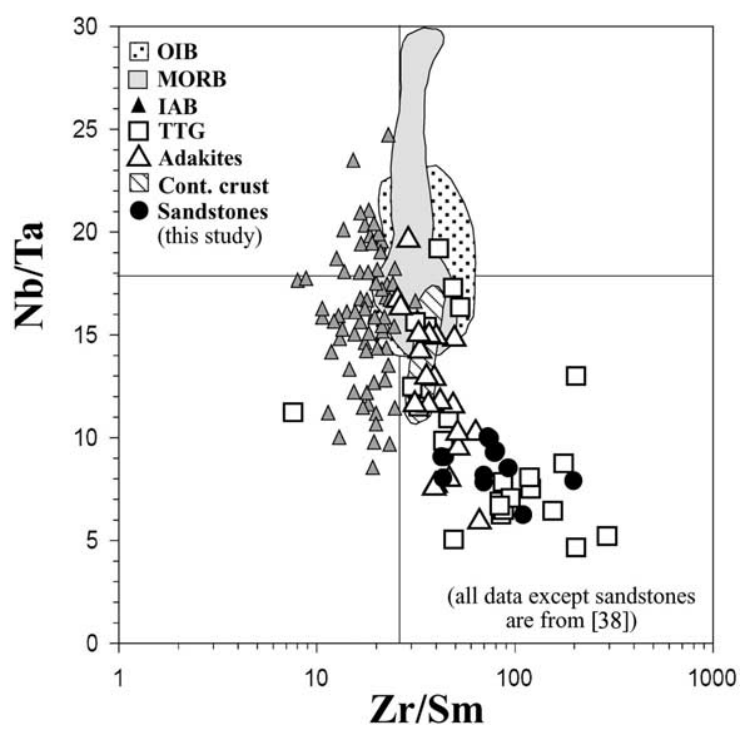

Fig. 7. $\mathrm{Nb} / \mathrm{Ta}$ ratios vs. $\mathrm{Zr} / \mathrm{Sm}$ ratios of the analyzed sandstones compared to Archean tonalite-trondhjemite gneisses (TTGs) and present day continental crust and adakites. Also shown are modern day MORBs, OIBs, and island arc basalts (IABs) [38]. The sandstones of this study are identical to Archean TTGs, indicating that the protoliths of the sandstones formed in similar petrotectonic environment. See text for discussions. 
shown from the literature [38]. The early continental crust represented by trondhjemite-tonalite-granodiorite gneisses (TTG) as well as modern adakites and continental crust lie in the lower right quadrant having sub-primitive mantle $\mathrm{Nb} /$ Ta ratios and super-primitive mantle $\mathrm{Zr} / \mathrm{Sm}$ ratios [38]. The sandstones fall in the lower right quadrant, remarkably identical to the Archean TTG having lower $\mathrm{Nb} / \mathrm{Ta}$ and higher $\mathrm{Zr} / \mathrm{Sm}$ values.

\subsection{Nd and $\mathrm{Sr}$ isotopes}

$\mathrm{Sr}$ and $\mathrm{Nd}$ isotopic data along with the $\mathrm{Nd}$ model ages for the sandstones are given in Table 3. The ${ }^{87} \mathrm{Sr} /{ }^{86} \mathrm{Sr}$ values are highly radiogenic, due to the ancient Archean age of the sandstones and their high $\mathrm{Rb}$ content $\left({ }^{87} \mathrm{Rb} /{ }^{86} \mathrm{Sr}\right.$ range is 2.4-9.0). Such highly radiogenic ${ }^{87} \mathrm{Sr} /{ }^{86} \mathrm{Sr}$ values are reported from Archean sediments from Greenland [39] and also seen in Archean shales in general [32]. An ${ }^{87} \mathrm{Sr} /{ }^{86} \mathrm{Sr}$ vs. ${ }^{87} \mathrm{Rb} /{ }^{86} \mathrm{Sr}$ isochron plot for these sandstones (not shown), however, gives an anomalously low age of $1.8 \mathrm{Ga}$, indicating postdepositional mobilization of $\mathrm{Rb}$.

$\mathrm{Sm}-\mathrm{Nd}$ concentrations along with the $\mathrm{Nd}$ isotopic data of the Archean sandstones from the Eastern Indian Craton are given in Table 3. $\varepsilon_{\mathrm{Nd}}(0)$ of the sandstones varies between -29 and -36 . The $f_{\mathrm{Sm} / \mathrm{Nd}}$ of the sandstones ranges from -0.32 to -0.40 . The $\varepsilon_{\mathrm{Nd}}(0)$ values of the amphibolites and tonalites [15] of this craton vary between -4 to -27 and between -38 to -49 , respectively. On a $f_{\mathrm{Sm} / \mathrm{Nd}}$ vs. $\varepsilon_{\mathrm{Nd}}(0)$ plot (Fig. 8 ), the sandstones plot almost precisely between the amphibolites and the tonalites. Along with the variation in the $\varepsilon_{\mathrm{Nd}}(0)$ values of the siliciclastic rocks there is also a small spread in their $f_{\mathrm{Sm} / \mathrm{Nd}}$ values.

Depleted mantle model ages $\left(\mathrm{T}_{\mathrm{DM}}\right)$ of the sandstones are shown in Table 3, assuming a linear growth in the $\varepsilon_{\mathrm{Nd}}$ value of the depleted mantle from $\varepsilon_{\mathrm{Nd}}=0$ at $4.56 \mathrm{Ga}$ to a present day value of +10 [40]. These model ages vary from 3.6 to $4.0 \mathrm{Ga}$. In Fig. 9, the Nd-isotopic evolutions of the sandstones are shown as growth lines from the

Table 3

$\mathrm{Rb}-\mathrm{Sr}$ and $\mathrm{Sm}-\mathrm{Nd}$ isotopic systematics of the sandstones and their respective depleted mantle Nd model ages

\begin{tabular}{|c|c|c|c|c|c|c|c|c|c|c|c|}
\hline Samples & $\begin{array}{l}\mathrm{Rb} \\
(\mathrm{ppm})\end{array}$ & $\begin{array}{l}\mathrm{Sr} \\
(\mathrm{ppm})\end{array}$ & $\frac{{ }^{87} \mathrm{Rb}}{{ }^{86} \mathrm{Sr}}$ & $\left({ }^{87} \mathrm{Sr} /{ }^{86} \mathrm{Sr}\right)^{\mathrm{a}}$ & $\begin{array}{l}\mathrm{Sm} \\
(\mathrm{ppm})^{\mathrm{b}}\end{array}$ & $\begin{array}{l}\mathrm{Nd} \\
(\mathrm{ppm})^{\mathrm{b}}\end{array}$ & $\frac{{ }^{147} \mathrm{Sm}}{{ }^{144} \mathrm{Nd}}$ & $\begin{array}{l}\left({ }^{143} \mathrm{Nd} /{ }^{144} \mathrm{Nd}\right)^{\mathrm{c}} \\
\pm 2 \text { s.e. }\end{array}$ & $\varepsilon_{\mathrm{Nd}}(0)^{\mathrm{d}}$ & $f(\mathrm{Sm} / \mathrm{Nd})^{\mathrm{e}}$ & $\begin{array}{l}T_{D M}{ }^{f} \\
(G a)\end{array}$ \\
\hline $23 / 96$ & 77.4 & 74.0 & 2.95 & 0.838550 & 1.65 & 8.82 & 0.118 & $0.510873 \pm 24$ & -34.4 & -0.40 & 3.61 \\
\hline $24 / 96$ & 74.6 & 32.5 & 6.49 & 0.921831 & 1.01 & 4.79 & 0.133 & $0.511063 \pm 34$ & -30.6 & -0.32 & 3.90 \\
\hline $25 / 96$ & 56.4 & 55.4 & 2.88 & 0.825799 & 1.98 & 9.82 & 0.127 & $0.510910 \pm 27$ & -33.7 & -0.35 & 3.92 \\
\hline $27 / 96$ & 42.9 & 14.1 & 8.57 & 0.973796 & 0.49 & 2.40 & 0.130 & $0.511110 \pm 45$ & -29.8 & -0.34 & 3.67 \\
\hline $30 / 96$ & 92.3 & 36.6 & 7.12 & 0.874257 & 1.01 & 5.10 & 0.125 & $0.510841 \pm 35$ & -35.1 & -0.36 & 3.95 \\
\hline $31 / 96$ & 85.4 & 42.6 & 5.66 & 0.906455 & 1.12 & 5.57 & 0.127 & $0.510930 \pm 25$ & -33.3 & -0.35 & 3.87 \\
\hline PRM/84 & 69.8 & 34.7 & 5.68 & 0.868211 & 0.81 & 4.25 & 0.121 & $0.510921 \pm 32$ & -33.5 & -0.38 & 3.65 \\
\hline $\mathrm{P} 3 / 96$ & 141.9 & 167.3 & 2.40 & 0.806794 & 4.38 & 23.37 & 0.119 & $0.510855 \pm 26$ & -36.3 & -0.40 & 3.77 \\
\hline P6/96 & 59.6 & 59.6 & 2.82 & 0.818952 & 1.31 & 6.65 & 0.125 & $0.510834 \pm 20$ & -35.2 & -0.37 & 3.93 \\
\hline
\end{tabular}

${ }^{\text {a }}$ Uncertainties for the measured ${ }^{87} \mathrm{Sr} /{ }^{86} \mathrm{Sr}$ ratios are less than 4 in the fifth decimal place $\left(2 \sigma_{\text {mean }}\right)$. Measured ${ }^{87} \mathrm{Sr} /{ }^{86} \mathrm{Sr}$ ratios are normalized to ${ }^{86} \mathrm{Sr} /{ }^{88} \mathrm{Sr}=0.1194$. NBS-987 Sr Standard analyzed during the course of this study yielded ${ }^{87} \mathrm{Sr} /{ }^{86} \mathrm{Sr}=0.710234 \pm 23$ $(2 \sigma)(n=4)$.

b $\mathrm{Sm}$ and $\mathrm{Nd}$ concentration were measured by isotope dilution using a mixed ${ }^{149} \mathrm{Sm}-{ }^{150} \mathrm{Nd}$ spike, uncertainties in these determinations are estimated to be less than $2 \%$.

c Uncertainties for the measured ${ }^{143} \mathrm{Nd} /{ }^{144} \mathrm{Nd}$ ratios corresponds to the fifth decimal place $\left(2 \sigma_{\text {mean }}\right)$. Some sample measurements were repeated. Measured ${ }^{143} \mathrm{Nd} /{ }^{144} \mathrm{Nd}$ ratios are normalized to ${ }^{146} \mathrm{Nd} /{ }^{144} \mathrm{Nd}=0.7219$. La Jolla Nd Standard analyzed during the course of this study yielded ${ }^{143} \mathrm{Nd} /{ }^{144} \mathrm{Nd}=0.511854 \pm 24(2 \sigma)(n=5)$.

d Calculated using the present-day bulk earth $(\mathrm{CHUR})$ values of ${ }^{143} \mathrm{Nd} /{ }^{144} \mathrm{Nd}=0.512638$. The $\varepsilon_{\mathrm{Nd}}(0)$ value represents the deviation of ${ }^{143} \mathrm{Nd} /{ }^{144} \mathrm{Nd}$ in parts of $10^{4}$ from the present day CHUR value.

e Enrichment factor $f_{\mathrm{Sm} / \mathrm{Nd}}$ calculated as $\left[\left({ }^{147} \mathrm{Sm} /{ }^{144} \mathrm{Nd}\right)_{\text {sample }} /\left({ }^{147} \mathrm{Sm} /{ }^{144} \mathrm{Nd}\right)_{\mathrm{CHUR}}-1\right]$ where CHUR is chondritic uniform reservoir and $\left({ }^{147} \mathrm{Sm} /{ }^{144} \mathrm{Nd}\right)_{\mathrm{CHUR}}=0.1968$.

f Depleted mantle model age of the rocks are estimated assuming a linear growth in the $\varepsilon_{\mathrm{Nd}}$ value of the depleted upper mantle using $\left({ }^{147} \mathrm{Sm} /{ }^{144} \mathrm{Nd}\right)_{\mathrm{DM}}=0.2136[40]$ and by taking the present day depleted mantle as $\varepsilon_{\mathrm{Nd}}(0)=10$. 


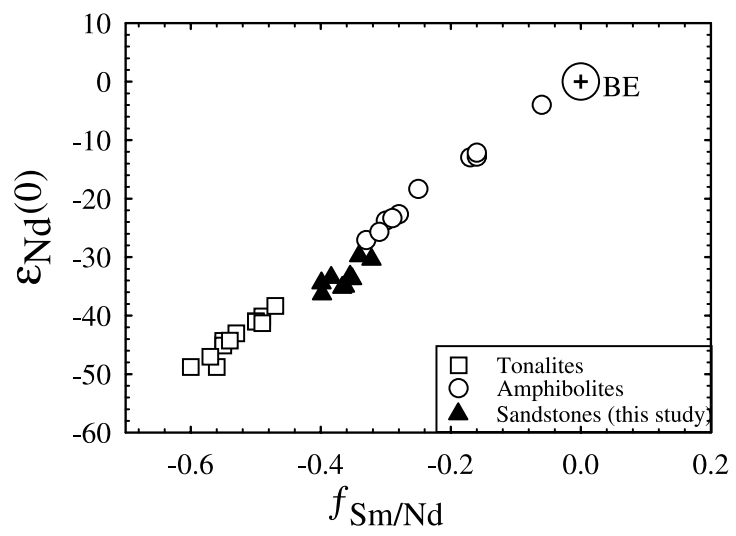

Fig. 8. $\varepsilon_{\mathrm{Nd}}(0)$ vs. $f_{\mathrm{Sm} / \mathrm{Nd}}$ plot for the sandstones and previously analyzed tonalites and amphibolites from the craton [15]. The sandstones plot between the more fractionated tonalites and less fractionated amphibolites. This relationship supports the observations from the rare earth element patterns (Fig. 4) that the geochemical characteristics of the sandstones reflect the bimodal mixing between the tonalites and amphibolites.

depleted upper mantle growth line to the present day. The Sm-Nd crystallization age of $3.3 \mathrm{Ga}$ [15] of the amphibolites and tonalites is designated by an arrow. It is interesting to note that all the other sandstones give higher than $3.3 \mathrm{Ga} \mathrm{T}_{\mathrm{DM}}$ ages including three sample with ages of $\sim 4.0$ $\mathrm{Ga}$. This observation suggests that $>3.8-\mathrm{Ga}$ crust may be present in this region of the Eastern Indian Craton.

\section{Discussion}

The Archean sandstones of this study plot in the continental block provenance fields in the $\mathrm{QFL}$ and $\mathrm{Q}_{\mathrm{m}} \mathrm{FL}_{\mathrm{t}}$ diagrams (Fig. 3). The quartzrich nature of the source OMTG is reflected in the plots of the sandstones near the quartz corner in the $\mathrm{QFL}$ and $\mathrm{Q}_{\mathrm{m}} \mathrm{FL}_{\mathrm{t}}$ plot. The trend of the sandstones towards the feldspar corner reflects a source for the sandstone with a composition similar to continental basements. When batholithic roots of arcs are exposed, their erosion is expected to give rise to quartzofeldspathic sands [31]. It is also possible that diagenesis has altered the original rock texture and clast composition [30] hence leading to an incorrect provenance interpretation
[29] from Fig. 3 since the pseudomatrix in the sandstones studied exceeds $10 \%$. The present clast composition of the sandstones as estimated in Table 1 may thus be due to the disintegration and dissolution of the lithic clasts, followed by pressure solutions along grain boundaries. A re-estimation of the lithic fragments would pull the sandstones towards the recycled orogen provenance field as indicated by the arrows in Fig. $3 a, b$. The loose constraints on the age of deposition of the Birtola Formation (between $\sim 3.16$ and $\sim 2.8 \mathrm{Ga}$ ) and the above ambiguity surrounding the lithic components of these rocks preclude a more definitive determination of tectonic setting of deposition. However, the presence of meta-igneous and meta-basic rock fragments in the sandstones supports the conjecture that the tonalites and amphibolites were the dominant source rocks for the sandstones. Trace element and isotopic data as presented above provide further evidence of the tectonic setting in the East Indian Craton at the time of sediment deposition.

The Iron Ore Group and the Singhbhum Granite volumetrically form the most prominent units in the Eastern Indian craton (Fig. 1) where the sandstones under discussion were deposited.

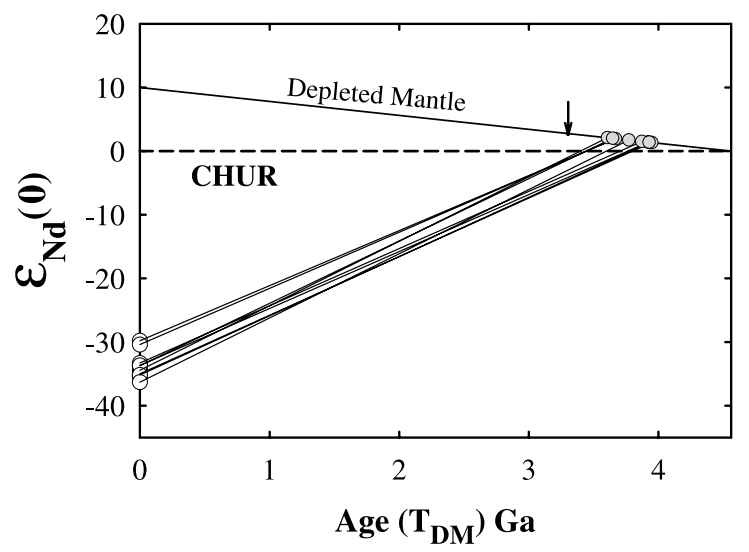

Fig. 9. On an $\varepsilon_{\mathrm{Nd}}$ vs. $\mathrm{T}_{\mathrm{DM}}$ plot, growth lines are shown from the calculated $\mathrm{T}_{\mathrm{DM}}$ (Table 3) to their respective present-day $\varepsilon_{\mathrm{Nd}}(0)$ values. The neodymium depleted mantle model ages of the sandstones are concentrated between 3.6 and $4.0 \mathrm{Ga}$, compared to the $\mathrm{Sm}-\mathrm{Nd}$ crystallization age of the amphibolites and tonalites [15], 3.3 Ga (arrow). The depleted mantle evolution curve as in [40] was used to calculate $\mathrm{T}_{\mathrm{DM}}$. 
Banded Iron Formation (BIF) and associated metavolcanic and metasedimentary rocks constitute the Iron Ore Group. Trace element concentrations of representative samples of BIF, quartzite and iron ores from this region are reported in [41]. Normalized REE patterns of quartzite and banded quartz magnetite show pronounced negative $\mathrm{Eu}$ anomalies while the BIF and iron ores show negative $\mathrm{Ce}$ anomalies. Metavolcanic rocks of the Iron Ore Group also show a strong negative Eu anomaly (our unpublished data). Volcanic rocks from the Iron Ore Group are known to display two types of REE patterns [42]: a flat pattern with a positive Eu anomaly, and another with LREE enrichment and a strong negative Eu anomaly. The Singhbhum Granite batholith, consisting of three phases of intrusion, displays in its third phase, constituting the major part of the pluton, a LREE enriched pattern with a strong negative Eu anomaly $[13,16,17]$. The Bonai Granite (Fig. 1), above which the sandstones were deposited, has an REE pattern similar to this third phase [17].

The REE patterns of the sandstones show an enriched LREE and a relatively flat HREE pattern with no Eu anomaly. If the granitoids or the Iron Ore Group rocks of the craton contributed significantly as a major source of the sandstones, an Eu anomaly would certainly be discernible in these sandstones. Ce anomalies are also absent from the sandstones. Thus from the REE distribution patterns alone, we infer that the granitoids and the Iron Ore Group of the craton were not possible contributors to the sandstones of this study. This inference is also supported by the sandstone petrography, which shows a low abundance of metasedimentary lithic clasts, ruling out sedimentary members of the Iron Ore Group.

The REE patterns of the sandstones, amphibolites and tonalites reported here are similar to those demonstrated by turbidites from Archean greenstone belts $[9,43]$. The average of the tonalite and amphibolite REE patterns shows a strong similarity with the average sandstone. The difference between the average of REE concentrations of the tonalites and amphibolites, and the sandstones is probably due to the dilution effect of quartz in the sandstones. The presence of poly- crystalline quartz $(\sim 1-5 \%)$ indicates that the Iron Ore Group metacherts and metaquartzites (Fig. 1) may have provided minor contributions to the sandstones, without affecting the REE patterns.

Sandstones are more likely to be affected by mineral sorting [9] than fine-grained sedimentary rocks like shales. This would be reflected in the REE patterns of the sandstones. Sandstones analyzed for this study differ in grain size from coarse to very fine-grained. However, all the sandstones show similar REE patterns, indicating that the heavy mineral sorting, if present, affected all the samples in a similar manner, regardless of their grain-size.

Comparisons of the primitive mantle-normalized incompatible and compatible trace element patterns of the sandstones with that of the average Archean and Proterozoic sandstones show a broad similarity in their patterns. The higher $\mathrm{Ba} /$ Th values in the sandstones from this study, along with their less conspicuous $\mathrm{Sr}$ depletion, compared to the average Archean and Proterozoic sandstones [32] could be due to the presence of more modal feldspars in these sandstones, as observed petrographically (Fig. 2a).

The $f_{\mathrm{Sm} / \mathrm{Nd}}$ vs. the $\varepsilon_{\mathrm{Nd}}(0)$ plot of Fig. 8 clearly shows that the sandstones fall between the amphibolite and tonalite data [15]. Because these rocks have undergone little metamorphism, the mobility of the REEs [44] of the sandstones was probably negligible. Thus $\mathrm{Sm}-\mathrm{Nd}$ isotope systematics data are consistent with the interpretation that the sandstones are a result of bimodal mixing between the tonalites and the amphibolites. This observation supports the inference that the REE and other immobile element characteristics of the sandstones reflect the geochemical signatures of their protoliths, the amphibolites and tonalites, providing information on the tectonic setting for the formation of these source rocks.

$\mathrm{Ce} / \mathrm{Pb}$ vs. the $\mathrm{Ce}$ concentration data (Fig. 6) show that the Archean shales from the Pilbara (3.4-2.7 Ga) craton [6] as well as the sandstones of this study do not fall within the field of present-day continental crust [35-37]. The fact that present-day continental crust has a $\mathrm{Ce} / \mathrm{Pb}$ value of around 4 compared to some demonstra- 
bly lower value in the Archean, such as in the sandstones of this study (Fig. 6), is noteworthy. This observation should provide constraints for recent discussions regarding the preferential partitioning of $\mathrm{Pb}$, apparently by a continuing geological process, from mantle into the continental crust via some non-magmatic transfer of mantle $\mathrm{Pb}$ into the subduction zone magmas [35].

Incompatible trace element patterns of the sandstones (Fig. 5) show a distinct $\mathrm{Nb}$, and in most samples, also a Ta depletion with respect to $\mathrm{Ba}$ and $\mathrm{La}$ when normalized to the primitive mantle. Such a Nb-Ta depletion is characteristic of present-day island arc magmas and is also evident in many sandstones of Archean and Proterozoic ages [32]. As already demonstrated in this study, the geochemical properties of the sandstones from the Eastern Indian Craton represent the geochemical signatures of their specific source rocks, the amphibolites and tonalites. Therefore the $\mathrm{Nb}-\mathrm{Ta}$ depletion was also present in these 3.3-Ga-old amphibolites and tonalites. Such a $\mathrm{Nb}$ and $\mathrm{Ta}$ depletion in the amphibolites and tonalites can thus be attributed to their formation in a subduction setting, similar to other Archean terranes that are believed to have formed by subduction accretion [1,5,21]. The super-primitive mantle $\mathrm{La} / \mathrm{Sm}, \mathrm{Zr} / \mathrm{Sm}$ and $\mathrm{Th} / \mathrm{Ta}$ ratios coupled with the sub-primitive mantle $\mathrm{Nb} / \mathrm{Th}, \mathrm{Nb} / \mathrm{Ta}$ and $\mathrm{Nb} / \mathrm{U}$ ratios of the sandstone-protoliths (Figs. 5 and 7) indicate slab-induced melting [1,2]. Thus the sandstone sources of tonalites and amphibolites formed in a subduction related tectonic setting. A similar mode of origin has also been suggested for some Archean granite-greenstones of the Superior Province [45] using the same geochemical analogy of the REE and high field strength elements. Depleted mantle model ages of the sandstones indicate ages greater than the age of the OMG and OMTG at $\sim 3.3 \mathrm{Ga}$. Nd model ages of $\sim 4.0$ Ga may imply that not only were the tonalites and amphibolites the source of the sandstones, there may also exist an older continental component in this part of the Indian Craton. The zircons from the OMG have indicated ${ }^{207} \mathrm{~Pb} /{ }^{206} \mathrm{~Pb}$ ages of $\sim 3.5-3.6 \mathrm{Ga}[22,46]$.

In the $\mathrm{Nb} / \mathrm{Ta}$ vs. $\mathrm{Zr} / \mathrm{Sm}$ plot (Fig. 7) the sandstones plot in the lower right quadrant with low
$\mathrm{Nb} / \mathrm{Ta}$ and high $\mathrm{Zr} / \mathrm{Sm}$ ratios, implying that the protoliths of the sandstones had similar trace element ratio signatures as in the Archean tonalitetrondhjemite gneiss [38]. Based on trace element partitioning results, partial melting of low-magnesium amphibolite or hydrous basalts in eclogite facies are viable mechanisms for the low $\mathrm{Nb} / \mathrm{Ta}$ and high $\mathrm{Zr} / \mathrm{Sm}$ ratios seen in the early continental crust $[2,38]$. Such melting of amphibolites or meta-basalts is likely to take place during subduction. It is significant that the protoliths of the sandstones of this study show similar $\mathrm{Nb} / \mathrm{Ta}$ and $\mathrm{Zr} / \mathrm{Sm}$ ratios as in Archean tonalite-trondhjemite gneisses (Fig. 7). This analogy gives strong support to our assertion that the sandstone protoliths of the amphibolites (metabasalts) and the tonalites were formed by subduction zone magmatism at $3.3 \mathrm{Ga}$ in the eastern Indian Craton.

The geochemical data presented above point to the formation of the amphibolites and tonalites in a subduction environment, which were exhumed when the Singhbhum Granite was being emplaced at depth. The arc signature expected on the QFL and $\mathrm{Q}_{\mathrm{m}} \mathrm{FL}_{\mathrm{t}}$ diagrams is not apparent in Fig. 3, perhaps due to the dissolution of the lithic clasts in the sandstones $[29,30]$ or the deeper dissection of arc assemblages exposing batholithic roots that may give rise to quartzofeldspathic sands [31]. Preponderance of the monocrystalline quartz in the sandstones has them plot in the continental block field with dominantly meta-igneous rocks as their protoliths.

Our geochemical data of the sandstones has established the OMG (amphibolites) and OMTG (tonalites) as the dominant sources of the sediment. We do not see trace elemental signatures characteristic of the Iron Ore group or the Singhbhum granite, although these lithologies are east of the Darjing Group (Fig. 1). This observation suggests that during the deposition of the Birtola Formation, the Singhbhum Granite batholithic complex did not have the aerial exposure that it does today. Intrusion of the Singhbhum Granite into the amphibolites and tonalites, the roots of the subduction arc, would cause their exhumation, and subsequent erosion and deposition in an adjacent trough. This petro-tectonic reconstruction would viably produce the geo- 
chemical signature that we see in the sandstones today.

\section{Conclusions}

(1) The trace element and isotope geochemistry, and petrography of the sandstones of the Birtola Formation and their source rocks suggest that the sandstones were derived from amphibolites and tonalites, two of the oldest known lithologic units in the Eastern Indian Craton.

(2) The characteristic $\mathrm{Nb}-\mathrm{Ta}$ depletion in the sandstones, considered here not as a result of heavy mineral sorting, is inferred to be present in the protoliths of the amphibolites and tonalites. This inference implies that the OMG and OMTG rocks formed in a subduction zone magmatic arc setting. Arc magmatism and accompanying metamorphism formed the tonalites and amphibolites in their roots, which were later exhumed, eroded, and deposited as the sandstone of the Birtola Formation.

(3) Lower $\mathrm{Nb} / \mathrm{Ta}$ and higher $\mathrm{Zr} / \mathrm{Sm}$ ratios of these sandstones indicate subduction zone melting of low-magnesium amphibolites or metamorphosed hydrous basalts to form the protoliths of these sandstones as described above. This conclusion is firmly based on recent trace element partitioning results, and indicates the existence of a subduction-accretion complex at ca. 3.3 Ga in the East India Craton.

(4) $\mathrm{Ce} / \mathrm{Pb}$ ratios in the Archean sandstones are variable and lower than the present-day average continental crustal value of 4 , and thus show that the Archean continental crust was already enriched in $\mathrm{Pb}$ having a much lower $\mathrm{Ce} / \mathrm{Pb}$ ratio than present day mantle.

(5) $\mathrm{Sm}-\mathrm{Nd}$ model ages of the sandstones with respect to the depleted mantle $\left(\mathrm{T}_{\mathrm{DM}}\right)$ range from $\sim 3.6$ to $4.0 \mathrm{Ga}$, clustering around higher than the 3.3-Ga-old crystallization ages of the tonalites and amphibolites. These higher model ages, as old as $\sim 4.0 \mathrm{Ga}$, suggest the presence of an older crustal component in the craton. This older component is probably present in the basement of the 3.3-Ga-old amphibolites and tonalites forming the roots of this subduction-related arc complex.

\section{Acknowledgements}

We are grateful to Dr. G. Wortman for technical help with the trace element analysis. Discussions with Dr. A. Basu of Indiana University were helpful for provenance analysis. We would like to thank Drs. T. Kusky and F. Kalsbeek for reviewing an early version of this paper. Drs. P.G. DeCelles, S.B. Jacobsen and T. Kusky are also thanked for their thorough and constructive reviews of this manuscript. This research was partially supported by NSF grants (A.R.B.) and a DST grant (Government of India - P.K.B. and A.C.). [SK]

\section{References}

[1] S.F. Foley, S. Buhre, D.E. Jacob, Evolution of the Archaean crust by delamination and shallow subduction, Nature 421 (2003) 249-252.

[2] R.P. Rapp, N. Shimizu, M.D. Norman, Growth of early continental crust by partial melting of eclogite, Nature 425 (2003) 605-609.

[3] S.M. McLennan, S. Hemming, D.K. McDaniel, G.N. Hanson, Geochemical approaches to sedimentation, provenance, and tectonics, Geol. Soc. Am. Spec. Pap. 284 (1993) 21-40.

[4] S.R. Taylor, S.M. McLennan, The Continental Crust: Its Composition and Evolution, Blackwell, London, 1985, 312 pp.

[5] M.G. Green, P.J. Sylvester, R. Buick, Growth and Recycling of early Archean continental crust: Geochemical evidence from the Coonterunah and Warrawoona Groups, Pilbara Craton, Australia, Tectonophysics 322 (2000) 69-88.

[6] S.M. McLennan, S.R. Taylor, K.A. Eriksson, Geochemistry of the Archean Shales from the Pilbara Supergroup, Western Australia, Geochim. Cosmochim. Acta 47 (1983) 1211-1222.

[7] B.K. Nelson, D.J. DePaolo, Comparison of isotopic and petrographic provenance indicators in sediments from Tertiary continental basins of New Mexico, J. Sediment. Petrol. 58 (1988) 348-357.

[8] A.R. Basu, M. Sharma, P.G. DeCelles, Nd, Sr-isotopic provenance and trace element geochemistry of Amazonian foreland basin fluvial sands, Bolivia and Peru; implications for ensialic Andean Orogeny, Earth Planet. Sci. Lett. 100 (1990) 1-17.

[9] S.R. McLennan, Rare earth element in sedimentary rocks: Influences of provenance and sedimentary processes, in: B.R. Lipin, G.A. McKay (Eds.), Geochemistry and Mineralogy of Rare Earth Elements, Reviews in Mineralogy, Min. Soc. Am., 1989, pp. 169-200. 
[10] M.T. McCulloch, G.J. Wasserburg, Sm-Nd and Rb-Sr chronology of continental crust formation, Science 200 (1978) 1003-1011.

[11] A.R. Basu, S.L. Ray, A.K. Saha, S.N. Sarkar, Eastern Indian 3800-million-year-old crust and early mantle differentiation, Science 212 (1981) 1502-1506.

[12] D. Mukhopadhyay, Precambrian of the Eastern Indian Shield - Perspective of the Problems, in: D. Mukhopadhyay (Ed.), Precambrian of the Eastern Indian Shield, Geological Society of India, Memoir 8, Bangalore, 1988, pp. 1-12.

[13] A.K. Saha, S.L. Ray, S.N. Sarkar, Early history of the Earth: Evidence from the Eastern Indian Shield, in: D. Mukhopadhyay (Ed.), Precambrian from the Eastern Indian Shield, Geological Society of India, Memoir 8, Bangalore, 1988, pp. 13-38.

[14] S. Moorbath, P.N. Taylor, N.W. Jones, Dating the oldest terrestrial rocks.... facts and fiction, Chem. Geol. 57 (1986) 63-86.

[15] M. Sharma, A.R. Basu, S.L. Ray, Sm-Nd isotopic and geochemical study of the Archean tonalite-amphibolite association from the eastern Indian Craton, Cont. Min. Pet. 117 (1994) 45-55.

[16] A.K. Saha, S.L. Ray, The structural and geochemical evolution of the Singhbhum granite Batholithic Complex, India, Tectonophysics 105 (1984) 163-176.

[17] S. Sengupta, D.K. Paul, J.R. deLaeter, N.J. McNaughten, P.K. Bandopadhyay, J.B. deSmeth, Mid-Archean evolution of the eastern Indian craton: Geochemical and isotopic evidence from Bonai pluton, Precamb. Res. 49 (1991) 23-37.

[18] A. Chakrabarti, P.K. Bandyopadhyay, A.K. Chakrabarti, Rounded fresh feldspar in the Late Archaean nearshore deposits around Patasahi, Orissa: Glacial activity?, Ind. J. Earth Sci. 25 (2001) 94-107.

[19] N.K. Mahalik, Geology of rocks lying between Gangpur Group and Iron Ore Group of the Horse Shoe Syncline in North Orissa, Ind. J. Earth Sci. 14 (1987) 73-83.

[20] P.K. Bandyopadhyaya, A.K. Chakrabarti, M.P. DeoMurari, S. Misra, $2.8 \mathrm{Ga}$ old granite-acid volcanics association from western margin of the Singhbhum-Orissa Craton, eastern India, Gond. Res. 4 (2001) 465-475.

[21] T.M. Kusky, A. Polat, Growth of the Granite-Greenstone Terranes at convergent margins and stabilization of Archean terranes, Tectonophysics 305 (1999) 43-73.

[22] A.R. Basu, M. Sharma, W.R. Premo, U-Pb age of an older metamorphic group mica schist; earliest terrain of the eastern Indian Craton, Recent Res. Geol. Geophys. Precamb. 16 (1996) 93-102.

[23] R.V. Ingersoll, T.F. Fullard, R.L. Ford, J.P. Grimm, J.D. Pickle, S.W. Sares, The effect of grain size on detrital modes; a test of the Gazzi-Dickinson point-counting method, J. Sediment. Petrol. 54 (1984) 103-116.

[24] W.R. Dickinson, C.A. Suczek, Plate tectonics and sandstone compositions, AAPG Bull. 63 (1979) 2164-2182.

[25] A. Basu, S.W. Young, L.J. Suttner, W.C. James, G. Mack, Re-evaluation of the use of undulatory extinction and polycrystallinity in detrital quartz for provenance interpretation, J. Sediment. Petrol. 45 (1975) 873-882.

[26] M.A.S. Moraes, L.F. de Ros, Depositional, infiltrated and authigenic clays in fluvial sandstones of the Jurassic Sergi Formation, Reconcavo Basin, northeastern Brazil, in: D.W. Houseknecht, E.D. Pittman (Eds.), Proc. 27th Annual Meeting of the Clay Minerals Society, Symposium on Origin, Diagenesis, and Petrophysics of Clay Minerals in Sandstone, 1992, 47, pp. 197-208.

[27] K.S. Matlack, D.W. Houseknecht, K.R. Applin, Emplacement of clay into sand by infiltration, J. Sediment. Petrol. 59 (1989) 77-87.

[28] W.R. Dickinson, Interpreting detrital modes of graywackes and arkose, J. Sediment. Petrol. 40 (1970) 695707.

[29] R. Cox, D.R. Lowe, Quantification of the effects of secondary matrix on the analysis of sandstone composition, and a petrographic-chemical technique for retrieving original framework grain modes of altered sandstones, J. Sediment. Res. 66 (1996) 548-558.

[30] R. Cox, E.D. Gutmann, P.G. Hines, Diagenetic origin for quartz-pebble conglomerates, Geology 30 (2002) 323-326.

[31] W.R. Dickinson, Interpreting provenance relations from detrital modes of sandstones, In: G.G. Zuffa (Ed.), Provenance of Arenites, Reidel, Dordrecht-Boston, 1985, pp. 333-361.

[32] K.C. Condie, Chemical composition and evolution of the upper continental crust: Contrasting results from surface samples and shales, Chem. Geol. 104 (1993) 1-37.

[33] S.R. Taylor, S.M. McLennan, The geochemical evolution of the continental crust, Rev. Geophys. 33 (1995) 241265.

[34] F. Bea, Residence of REE, Y, Th and U in granites and crustal protoliths; Implications for the chemistry crustal melts, J. Petrol. 37 (1996) 521-552.

[35] D.M. Miller, S.L. Goldstein, C.H. Langmuir, Cerium/ Lead and lead isotope ratios in arc magmas and the enrichment of lead in the continents, Nature 368 (1994) 514 520 .

[36] A.W. Hofmann, K.P. Jochum, M. Seufert, W.M. White, $\mathrm{Nb}$ and $\mathrm{Pb}$ in oceanic basalts: New constraints on mantle evolution, Earth Planet. Sci. Lett. 79 (1986) 33-45.

[37] C. Chauvel, S.L. Goldstein, A.W. Hofmann, Hydration and dehydration of oceanic crust controls $\mathrm{Pb}$ evolution in the mantle, Chem. Geol. 126 (1995) 65-75.

[38] S. Foley, M. Tiepolo, R. Vannucci, Growth of early continental crust controlled by melting of amphibolite in subduction zones, Nature 417 (2002) 837-840.

[39] F. Kalsbeek, Use of $\mathrm{Rb}-\mathrm{Sr}$ isotope data to constrain the time of deposition of Precambrian metasediments: An example from Hamborgerland, West Greenland, Rep. Geol. Surv. Greenland 159 (1993) 95-100.

[40] S.J. Goldstein, S.B. Jacobsen, Nd and Sr isotopic systematics of river water suspended material; implications for crustal evolution, Earth Planet. Sci. Lett. 87 (1988) 249 265.

[41] T. Majumder, J.E. Whitley, K.L. Chakraborty, Rare- 
earth elements in the Indian Banded Iron Formation, Chem. Geol. 45 (1984) 203-211.

[42] S. Sengupta, S.K. Acharyya, J.B. DeSmeth, Geochemistry of Archaean volcanic rocks from the Iron Ore Supergroup, Singhbhum, Eastern India, Proc. Indian Acad. Sci. (Earth Planet. Sci.) 106 (1997) 327-342.

[43] S.M. McLennan, S.R. Taylor, Sedimentary rocks and crustal evolution; tectonic setting and secular trends, J. Geol. 99 (1991) 1-21.

[44] D.K. McDaniel, S.R. Hemming, S.M. McLennan, G.N. Hanson, Resetting of neodymium isotopes and redistribution of REEs during sedimentary processes: The Early
Proterozoic Chelmsford Formation, Sudbury Basin, Ontario, Canada, Geochim. Cosmochim. Acta 58 (1994) 931-941.

[45] A. Polat, R. Kerrich, Archean greenstone belt magmatism and the continental growth-mantle evolution connection; constraints from $\mathrm{Th}-\mathrm{U}-\mathrm{Nb}$-LREE systematics of the 2.7 Ga Wawa Subprovince, Superior Province, Canada, Earth Planet. Sci. Lett. 175 (2001) 41-54.

[46] S. Mishra, M.P. Deomurari, M. Wiedenbeck, J.N. Goswami, S. Ray, A.K. Saha, ${ }^{206} \mathrm{~Pb} /{ }^{207} \mathrm{~Pb}$ zircon ages and the evolution of the Singhbhum Craton, eastern India, an ion microprobe study, Precamb. Res. 93 (1999) 139-151. 